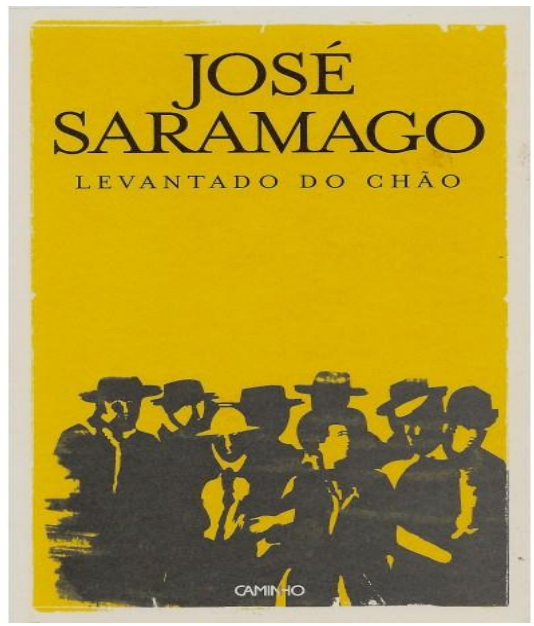

\title{
Um olhar sobre o levantado do chão
}

Luciana de Oliveira Mangueira $^{1}$

Escreveu José Saramago no Levantado do Chão: "Quando as dores são muito grandes, são os olhos que não suportam vê-las" (SARAMAGO, 2009, p. 336). Por isso não poderemos ver o homem, a luta, a polícia, a verdade, nada. Tomemos, pois, por empréstimo, os olhos das formigas com cabeça de cão que passeiam por uma sala em um dos episódios do livro e andemos no romance.

Reúnem-se os homens na praça de touros, mas a cena em questão, dessa vez, não trata de uma tourada. Eles são os grevistas acusados pela armada e estão postos no lugar dos touros prontos para o açoite. Esses homens representam uma ameaça à propriedade e à ordem, eis o crime. Os "grevistas" de Levantado do Chão são aqueles trabalhadores considerados pela política do latifúndio como desordeiros, preguiçosos, que não respeitam as leis naturais das coisas: trabalhar e obedecer ao sistema - "trabalharás para mim de sol a sol em todos os dias da tua vida que me aprouver e convenha, nos outros farás o que quiseres." (SARAMAGO, 2009, p. 338). Esses personagens, transgressores, movimentam-se em busca de uma vida melhor. A princípio, inocentes, vão até o patrão com esperança de que esse ouça as reivindicações, mas, no decorrer do romance, o movimento dos trabalhadores vai se organizando, pois percebem que precisam unir forças para a conquista de seus objetivos como o aumento de salário e redução na jornada de trabalho. Essa organização trabalhista é vista pelo poder vigente como algo

\footnotetext{
${ }^{1}$ É mestranda em Literatura Portuguesa pela UERJ e especialista em Literatura Portuguesa e Africanas pela UFRJ.
} 
extremamente nocivo aos interesses do latifúndio/estado. Dessa forma, as maneiras de tentar reprimi-los se tornam cada vez mais incisivas e violentas.

Da praça dos touros retira-se um nome: Germano Santos Vidigal. O homem, dado como perigoso, será levado para a hermética sala de onde se espera que confesse seu delito e que entregue os companheiros. Esse lugar é cerrado, como havíamos de esperar de uma sala de tortura, e lá não podemos entrar, nem narrador, nem autor, somente as formigas. Essa alegoria usada por Saramago aparece pela primeira vez no romance testemunhando essa cena. O narrador, impedido de ver, se guiava pelo olhar das formigas que por ali passavam no seu caminho rotineiro de trabalho: fazerem dez viagens até chegar a hora da morte. As formigas tudo viam e foram as únicas testemunhas de um crime da polícia contra o homem que, de apanhar, morreu sem ao menos dizer uma palavra ao interrogatório. Ora, esses mesmos que agora queriam forçálo a falar passaram toda uma vida ensinando e obrigando-o justamente ao contrário: calar, manter-se incógnito, aceitar e acatar.

Essa cena de tortura chega até nós através de uma voz narrativa que, nesse momento, declara sua impotência diante do fato. Os movimentos da sala são revelados para o narrador no mesmo momento que para nós, leitores, gerando uma cumplicidade e consequente posicionamento diante do ocorrido: "não saberemos que pensamentos são e serão o dele [do preso] agora o que é preciso é pormo-nos nós a pensar" (SARAMAGO, 2009, p. 167-168). Há uma curiosidade gradativa e indignação presente nesse desenrolar que colocam claramente o narrador em um posicionamento político - nessa luta, ele está do lado do trabalhador rural, não só o da sala, mas todo o qual aquele representa.

Tomando o ocorrido com Germano Santos Vidigal como uma cena metonímica para todo o romance, percebemos que os quase cem anos de duração da narrativa podem ser associados àquelas horas que duram a tortura, que duram as 10 viagens das formigas. A obra perpassa fatos históricos importantes de Portugal, como a chegada da República em 1910, a I Guerra Mundial, a ascensão da ditadura Salazarista e a Revolução dos Cravos. Todos esses momentos chegavam ao romance sob a perspectiva do homem do campo, que pouco os reconhecia e menos ainda entendia o que representavam, sabia apenas aquilo que chegava pelos jornais ou através do preço dos produtos que aumentava cada vez mais.

Como o foco narrativo da obra é voltado para o trabalhador, o leitor encontrase diretamente envolvido pelos problemas das personagens visto ser o narrador 
onisciente àquele povo o qual retrata. Valendo-se dessa aproximação, todas as vivências campestres podem ser sentidas de maneira contundente pelo leitor que consegue incomodar-se com a fome das personagens, pode sentir o cansaço por que passam e ainda mais a indignação com as injustiças às quais são submetidas ao longo do romance.

Esse longo período de tempo possui como determinante o acompanhar de uma família, os Mau Tempo, que se vê acompanhada através do decorrer de gerações. É através dessa família que toda a rotina no latifúndio é retratada. As duras e massacrantes jornadas de trabalho só não causam mais desespero que a falta de serviço e a visão que os senhores de terra têm é a de que são os camponeses preguiçosos e arruaceiros revoltosos quando resolvem se queixar ou rebelar-se contra as vigentes regras do latifúndio.

Esse posicionamento do autor revela o caráter imediatamente político do romance, que aparece não apenas por falar de política, mas por tentar (e conseguir) enxergar o outro, aquele que é diferente de nós: "O romance mais político (...) é aquele que tenta ver tudo e entender a todos, construir o todo mais amplo. Assim, o romance que consegue realizar essa tarefa impossível tem o centro mais profundo" (PAMUK, 2011, p. 105). Em Levantado do Chão, o tom denunciador do autor faz chegar aos ouvidos do mundo uma voz local, normalmente presa nos limites da cerca, do homem da terra, mas que, sem ela, se torna cada vez menos homem.

Os homens do campo em Monte Lavre ${ }^{2}$ são formigas com cabeça de cão: veem cenas de torturas, têm seus familiares levados pela polícia, mas não podem falar porque não têm voz. Assim como as formigas, o homem não a tem, sua voz não chega à capital, não há quem ouça. Dessa maneira, "sobre esses casos hão de passar os anos e há de pesar o silêncio até que as formigas tomem o dom da palavra e digam a verdade e só a verdade" (SARAMAGO, 2009, p. 176).

As formigas com cabeça de cão somos nós, leitores, e percorremos todo romance como aquelas que testemunham a cena de Germano Santos Vidigal durante as dez viagens que fazem do formigueiro à sala em que se passa a ação. A $11^{\text {a }}$ viagem é a leitura do livro, e faremos como elas - "de tudo isso mais tarde se farão longas conversas no formigueiro para ilustração das gerações futuras, que aos novos é útil saberem o que vai pelo mundo" (SARAMAGO, 2009, p. 169) - para entender que "a

\footnotetext{
${ }^{2}$ Espaço do romance Levantado do Chão.
} 
luta do homem contra o poder é a luta da memória contra o esquecimento" (KUNDERA, 2009, p. 120).

\section{Referências Bibliográficas}

KUNDERA, Milan. A arte do romance. São Paulo: Companhia das Letras, 2009.

PAMUK, Orhan. O romancista ingênuo e o sentimental. São Paulo: Companhia das Letras, 2011.

SARAMAGO, José. Levantado do Chão. 15. ed. Rio de Janeiro: Bertrand Brasil, 2009. 